\title{
Effect of the Dry Matter Intake Level on the Sanguine Profile of Glucose, Insulin, Urea, Estrogen and Progesterone and Concentration of IGF-I in the Follicular Liquid of Crossbred Heifers
}

\author{
Luiz Paulo Rigolon, Ivanor Nunes do Prado, Fábio Luiz Bim Cavalieri, Willian Gonçalves \\ do Nascimento, Luiz Carlos Copovila, Fabíola dos Santos Ramos and Fernanda Barros \\ Moreira* \\ Universidade Estadual de Maringá; Av. Colombo, 5790; 87020-900; Maringá - PR - Brasil
}

\begin{abstract}
The aim of this work was to study effect of the dry matter intake level on the concentrations of glucose, insulin, urea, estrogen and progesterone in the blood and the level of IGF-I in the follicular liquid of heifers. Twenty seven crossbred heifers were used, in three treatments: 1.2, 1.6 and 2.6\% of the live weight of dry matter intake (DMI) daily. The sanguine concentrations of glucose and estrogen were higher in the animals with 1.6\% of DMI and the insulin levels were higher in the animals with 2.6\% of DMI. There was an increase in the sanguine levels of urea with the increase of the DMI. There was no effect of the DMI on the progesterone levels in the sanguine plasma collected from the jugular. The progesterone levels in caudal vena were higher in the animals with $2.6 \%$ of DMI. There was no effect of the DMI on the follicular levels of IGF-I.
\end{abstract}

Key words: FSH, Hormones, Intake, Nutrition, Reproduction, Superovulation

\section{INTRODUCTION}

The reproductive parameter is one of the main factors that determine the profitability of a cattle property. Lately, with the implementation of the animal selection, associated with its best handling, has made it possible a significant increase in the productivity of the tropical herds. However, the same has not been observed with the reproductive variables. These variables either stagnated or decreased in the last few years, coming in an inverse way to animal production (Butler, 2000).
The nutritional status of an animal is one of the main factors responsible for its fertility (Robinson et al., 1999). Among the nutritional factors responsible for the reproductive variables, the level of crude protein (Garcia-Bojalil et al., 1994), vitamin A (Shaw et al., 1995), fat (Thomas et al., 1997) and energy density of the diet (O'Callaghan and Boland, 1999) are important. However, some of the mechanisms involved in the nutrition effects of the animal reproduction are not still completely explained (Chagas et al., 2007).

\footnotetext{
* Author for correspondence: fbmoreira@ pubvet.com.br
} 
The energy density of the diet seems to be one of the main factors involved in the follicular growth, ovulation and embryonic development. Studies with sheeps have shown that an increase in the level of energy of the diet for a short period increases the number of follicles, and as a result, the ovulation rate (Leury et al., 1990; Molle et al., 1995; Brustolini et al., 2004). Although bovine are monovulatory species, the effects on the follicular growth seem to be similar (Gutierrez et al., 1997).

The embryos transference has been considered one of the main techniques to the animal reproduction, after the artificial insemination, because it also values the reproductive potential of the females. Though, the number of follicles responsive to the gonadotrophins, in the beginning of the hormonal treatments, seems to be one of the factors that alter the superovulatory answer and the production of embryos (Gong et al., 1997).

The mechanism that causes the higher level of energy in the diet to elevate the number of follicles seems to be mediated by alterations in the sanguine concentrations of glucose $\left(\mathrm{O}^{\prime} \mathrm{Callaghan}\right.$ and Boland, 1999), insulin (Landau et al., 2000),
IGF-I and their connecting proteins (Armstrong et al., 2000) and progesterone (O'Callaghan et al., 2000).

The objective of this work was to study the effect of the dry matter intake (DMI) level on the concentrations of glucose, insulin, urea, estrogen and progesterone, in the plasma of the jugular vein; progesterone in the plasma of the caudal vena and IGF-I in the follicular liquid of crossbred heifers.

\section{MATERIALS AND METHODS}

A total of 27 crossed heifers ( $1 / 2$ Nelore x $1 / 2$ Simmental) with age of 16 months and live weight of $361 \mathrm{~kg}$ were used. All animals had normal estrous cycles and they were clinically healthy. The heifers were randomly allocated to one of the three treatments, according to their dry matter intake (DMI) proportionally to their live body weight (\% of $\mathrm{BW}$ ): $1.2 ; 1.6$ and $2.6 \%$ of $\mathrm{BW}$ of DMI.

Table 1 - Ingredients intake $(\mathrm{kg})$ by the heifers feeding dry matter in the levels of $1.2,1.6$ or $2.6 \%$ of body weight (BW).

\begin{tabular}{lccc}
\hline Diets & $\mathbf{1 . 2 \%} \mathbf{B W}$ & $\mathbf{1 . 6 \%} \mathbf{~ B W}$ & $\mathbf{2 . 6 \%} \mathbf{B W}$ \\
\hline Corn silage & 2.17 & 2.90 & 4.71 \\
Corn Grain & 1.73 & 2.30 & 3.74 \\
Soybean Meal & 0.40 & 0.53 & 0.87 \\
Mineral Salt & 0.04 & 0.05 & 0.07 \\
Total & 4.33 & 5.78 & 9.39 \\
\hline
\end{tabular}

The heifers were housed in individual stalls of 10 square feet each, concreted ground, enclosed with iron bars, with an area covered with zinc tiles and solarium. The feeding was supplied in feeders made of masonries with 2 square feet linear per animal. The water was made available ad libitum in located watering places in the uncovered area of the facilities.

The diets were formulated according to the NRC (1996) recommendations, aiming to assist the demands of cattle heifers with medium weight of $361 \mathrm{~kg}$ (Table 1). The ration was fed twice a day, at 8:00 a.m. and at 4:00 p.m.

After 142 days consuming the diets, estrus was synchronized in all the heifers using two doses of PGF2 $\alpha$ (Preloban ${ }^{\circledR}$, Hoechst Vet S.A.) with interval of 14 days between the first and second application. Superovulatory treatment was initiated nine days after synchronized estrus. A total dose of 250 UI of gonadotrophic hormone (FSH - Pluset Calier) divided in two daily decreasing doses, for four days was used. In the sixth application of FSH (D11), a dose of PGF2 $\alpha$ (Preloban ${ }^{\circledR}$, Hoechst Vet S.A.) was administered (Table 2).

Five animals of each treatment were catheterized in the caudal vena according to the technique described by Benot and Dailey (1991) and modified by Rhodes et al. (1995). The location of the extremity of the catheter in the caudal vena, near the drained blood of the uterus and ovary, was confirmed through the transrectal palpation and a Scanner 480 ultrasound apparel (Pie Medical with a probe of 5.0 MHZ). 
Table 2 - Superovulatory treatment design.

\begin{tabular}{ccc}
\hline Day & Hours & FSH Dose $($ UI $)$ \\
\hline Zero & Estrus & 60 \\
9 & $7: 00$ & 60 \\
& $19: 00$ & 35 \\
10 & $7: 00$ & 35 \\
& $19: 00$ & $20+$ PGF $2 \alpha$ \\
11 & $7: 00$ & 20 \\
& $19: 00$ & 10 \\
& $7: 00$ & 10 \\
\hline
\end{tabular}

Samples of blood were collected in heparinized tubes, and then centrifuged at $3200 \mathrm{rpm}$ for 20 minutes. The plasma was separated, conditioned in eppendorf flasks and stored at $-20^{\circ} \mathrm{C}$. The samples were picked by puncture of the jugular vein and of the catheter inserted in the caudal vena every other day, from the moment of the estrus, until the last day of the superovulatory treatment (D12), aiming to analyze the progesterone concentrations (Fluorimetry, Rhesus ${ }^{\circledR}$ ). Starting from the 8th (D12) application of the gonadotrophic hormone, 11 samples of blood of the jugular vein were collected every $4 \mathrm{~h}$ to determine the concentrations of glucose (enzymatic glucose oxidase-peroxidase method), insulin (Enzyme Linked Imunosorbent Assay (ELISA) method), urea (enzymatic ureaseglutamate-dehydrogenase method) and estrogen (Enzyme Linked Imunosorbent Assay (ELISA) method).

In the other four animals of each treatment, in the 7th application of FSH (D12), ovariectomy was accomplished. The ovaries were maintained at $37^{\circ}$ $\mathrm{C}$ and taken to the laboratory, where the liquid of the medium sized follicles $(5-9 \mathrm{~mm})$ and big sized $(>10 \mathrm{~mm})$ were aspirated and later stored in Eppendorf flasks at $-20^{\circ} \mathrm{C}$, for the IGF-I analyses (ELISA) (Spicer et al., 1992).

Data were subjected to statistical analysis using the SAS program (SAS, 1998). There were three treatments and five repetitions for the sanguine hormonal analyses and four repetitions for the hormonal analyses in follicular fluids, according to the statistical model presented below:

$Y i j=\mu+\mathrm{Ti}+\mathrm{Cj}+\mathrm{TSij}+$ eijk

Where:

Yij = Observation regarding the animal $\mathrm{j}$, submitted to the treatment $i$ ( $i=1,2$ and 3); $\mu=$ General constant associated to each observation;

$\mathrm{Ti}=$ Effect of the treatment $\mathrm{i}(\mathrm{i}=1,2$ and 3);

$\mathrm{Sj}=$ Effect of the sample $\mathrm{j}(\mathrm{j}=1 \ldots 11)$;

Eijk $=$ Random error associated to each observation.

\section{RESULTS}

The animals that ingested $1.6 \%$ of dry matter (DM) showed higher $(\mathrm{P}<0.05) \quad$ sanguine concentrations of glucose $(83.02 \mathrm{mg} / 100 \mathrm{ml})$, when compared to the animals that ingested 1.2 and $2.6 \%$ of $\mathrm{DM}(77.61 \mathrm{mg} / 100 \mathrm{ml}$ and 76.56 $\mathrm{mg} / 100 \mathrm{ml}$, respectively) (Fig. 1).

The animals of the treatment with $2.6 \%$ of DMI presented higher $(\mathrm{P}<0.001)$ sanguine concentration of insulin $(13.96 \mu \mathrm{U} / \mathrm{l})$, in comparison with the animals of the treatment $1.2 \%(5.41 \mu \mathrm{U} / \mathrm{l})$ and $1.6 \%(7.25 \mu \mathrm{U} / \mathrm{l})$ of DMI (Fig. 2).

The sanguine levels of urea increased $(\mathrm{P}<0.001)$ as the DMI increased (Fig. 3). The animals with level of DMI $1.2 ; 1.6$ and $2.6 \%$ presented, on average, $12.80,17.91$ and $19.90 \mathrm{mg}$ of urea per $100 \mathrm{ml}$ of blood, respectively.

The treatment with $1.6 \%$ of DMI presented higher $(\mathrm{P}<0.05)$ sanguine concentration of estradiol $(1796.93 \mathrm{pg} / \mathrm{ml})$ when compared to the treatment with 1.2 and $2.6 \%$ of DMI $(1232.79 \mathrm{pg} / \mathrm{ml}$ and $1451.61 \mathrm{pg} / \mathrm{ml}$, respectively) (Fig. 4).

There was no effect $(\mathrm{P}>0.10)$ of the DMI level on the progesterone concentration in the sanguine plasma collected in the external jugular (6.70 $\mathrm{ng} / 100 \mathrm{ml}, 7.28 \mathrm{ng} / 100 \mathrm{ml}$ and $9.88 \mathrm{ng} / 100 \mathrm{ml}$, for the levels of $1.2 \% ; 1.6 \%$ and 2.6\%) (Fig. 5) 


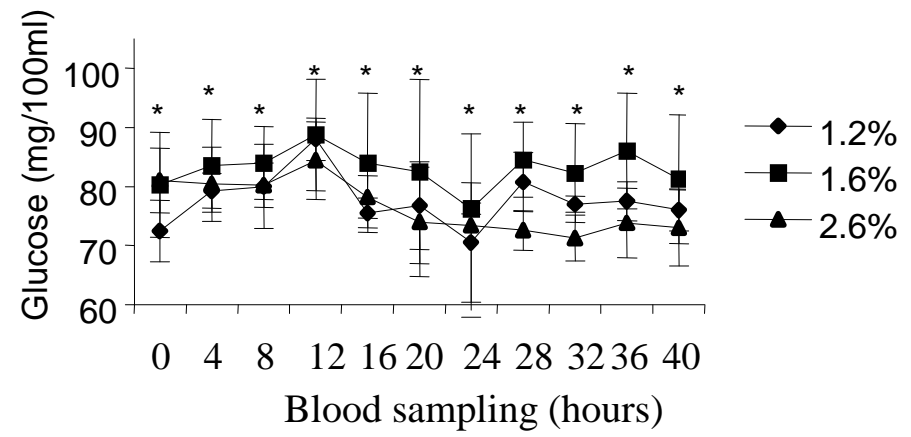

Figure 1 - Effect of the DMI levels on the glucose sanguine concentration $(\mathrm{mg} / 100 \mathrm{ml})$, in function of the time.

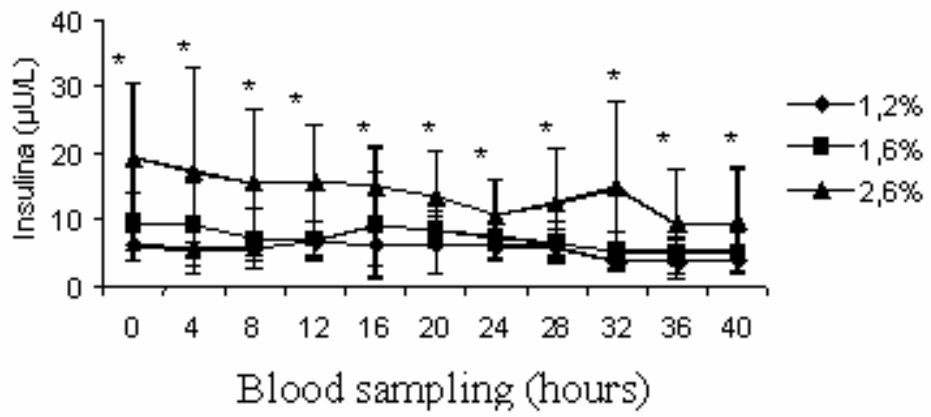

Figure 2 - Effect of the DMI level on the insulin sanguine concentration $(\mu \mathrm{U} / \mathrm{L})$, in function of the time.

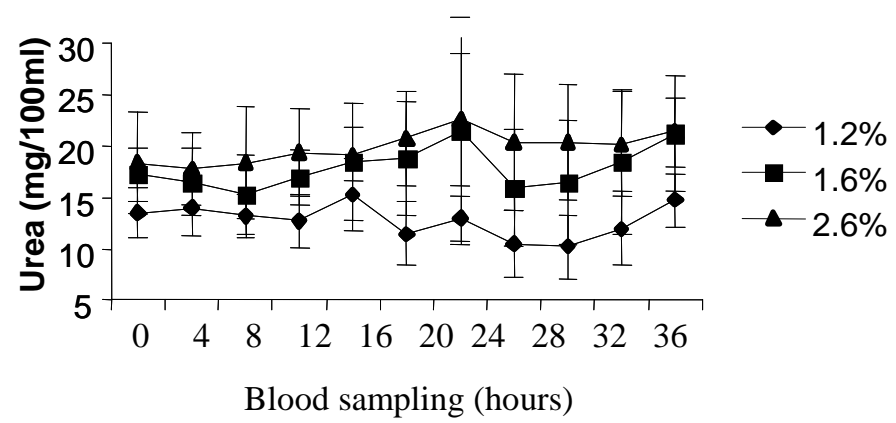

Figure 3 - Effect of the DMI level on the urea sanguine concentration (mg/100 $\mathrm{ml})$, in function of the time.

However, there was an effect $(\mathrm{P}<0.03)$ of the DMI level on the progesterone concentration in the sanguine plasma collected in the caudal vena. The progesterone levels were higher $(\mathrm{P}<0.05)$ in the animals with $2.6 \%$ of DMI $(11.77 \mathrm{ng} / 100 \mathrm{ml})$, in relation to the animals with $1.2 \%$ of DMI (6.39 $\mathrm{ng} / 100 \mathrm{ml})$ and didn't differ $(\mathrm{P}<0.05)$ of the animals with $1.6 \%$ of DMI (8.2 ng/100ml) (Fig. 6)
In spite of existing effects of the treatment in the sanguine concentrations of several hormones, there was no effect of the DMI level $(\mathrm{P}>0.05)$ on the concentration of IGF-I. The levels of IGF-I in the ovarian fluid were of $327.76,282.82$ and $258.32 \mathrm{ng} / \mathrm{ml}$ of blood. 


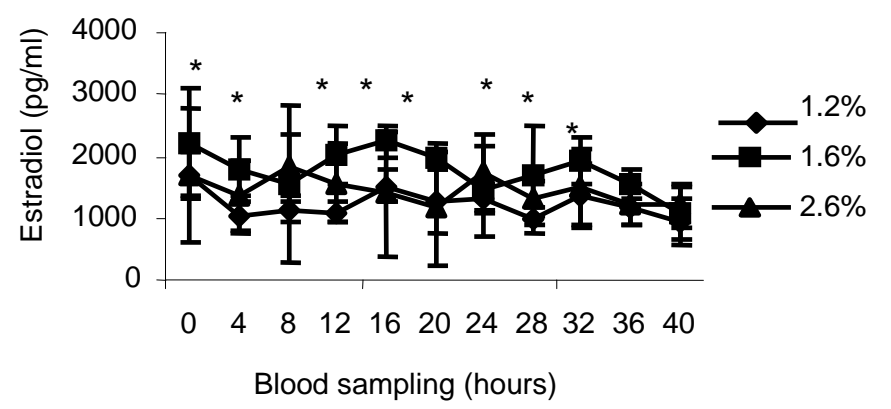

Figure 4 - Effect of the DMI levels on the estradiol sanguine concentration (pg/ml), in function of the time.

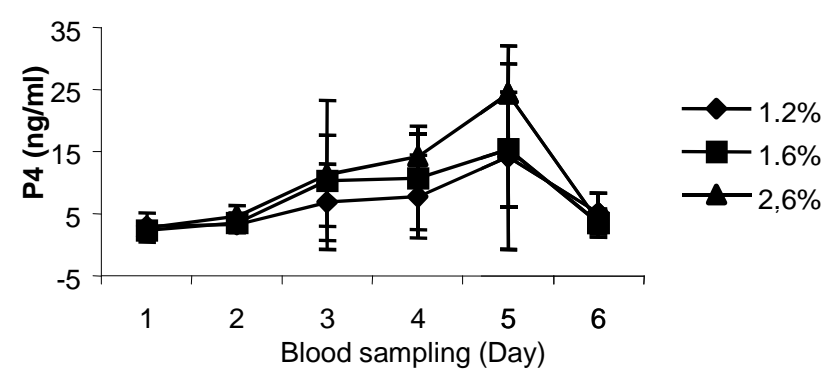

Figure 5 - Effect of the DMI levels on the progesterone - P4 sanguine concentration (ng/ml), in function of the time.

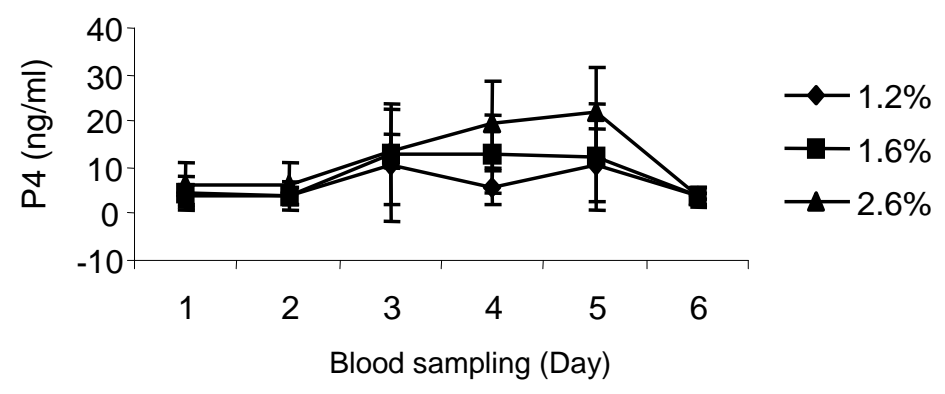

Figure 6 - Effect of the DMI level on the progesterone - P4 sanguine concentration (ng/ml), collected of the catheter inserted in the vena, in function of the time.

\section{DISCUSSION}

The glucose is considered an important metabolite involved in the regulation of the follicular growth (Molle et al., 1995). Shorts and Adams (1988) found that the glucose was the specific mediator of the nutrition effects of the animal reproduction. The supply of diets rich in cereal grains to the cattle alters the population of microorganisms of the rumen, as well as the production and the ratio of volatile fatty acids produced (Teleni et al., 1989), increasing the production of propionic acid 
(Silva and Leão, 1979). This acid, considered gluconeogenic (O'Callaghan and Boland, 1999), promotes an increase in the circulating glucose levels (Leury et al., 1990). Therefore, the increase in the consumption of dry matter could have caused a higher production of propionic acid in the rumen, what resulted in a higher concentration of sanguine glucose.

However, it is worth to observe that in this experiment the animals of the treatment with higher intake level (2.6\% of DMI) presented smaller glucose concentrations than those fed with $1.2 \%$ and $1.6 \%$ of DMI, respectively. These results could be explained, partly, because of the higher concentration of circulating insulin observed in the animals fed with $2.6 \%$ of DM.

The insulin is intimately related to the level of circulating glucose (Downing et al., 1995) and presents several functions related mainly with the follicular dynamics, such as proliferation and differentiation of the cells of the granular (Spicer and Echternkamp, 1995), steroidogenesis and a number of small, medium and big follicles (Downing et al., 1995). Gutiérrez et al. (1997) found that the effects of the energy increase in the diet on the follicular growth were a result of the increase of the concentration of circulating insulin. Downing et al. (1995) observed that the infusion of fatty acids of a ramified chain or the inclusion in the diet of foods rich in leucine also increased the concentration of plasmatic insulin (Landau et al., 1996).

Hence, the treatment of $2.6 \%$ of BW of DMI could have resulted in an increase in the cattle metabolism, what would unchain the increase in the production of propionic acid and fatty acids of a ramified chain, contributing to increase the sanguine concentrations of insulin. Bassett et al. (1971) demonstrated that the concentration of plasmatic insulin presented positive correlation with the amount of organic matter or digestible protein ingested by the animal.

It would be worth to emphasize that the rations were isoproteic, so that the increase of DMI provided the increase in the intake of crude protein, which resulted in larger amount of ammonia produced in the rumen, causing the increase in the production and flow of microbial protein for the small intestine, elevating the circulating levels of urea.

Several studies have shown that the urea increase in the sanguine circulation alters the animal reproduction negatively (Santos and Amstalden,
1998; Garcia-Bojalil et al., 1994). The negative effect of the urea has been related to the decrease of the uterine $\mathrm{pH}$ (Elrod and Butler, 1993), which could harm the initial embryonic development (Santos and Amstalden, 1998). Fergunson et al. (1993) stated that the conception rate in the herd decreased when the circulating levels of urea were above $20 \mathrm{mg} / 100 \mathrm{ml}$. In this experiment, all of the treatments presented, on average, levels below this as responsible for the negative effects in the reproduction.

The estradiol is produced in the granular cells by the developing follicle from the androgenics synthesized by the Theca cells (Ginther et al., 1996). The number of developing follicles was not evaluated in this experiment, but the increase in the estradiol levels could be an indicative of the increase in the number of follicles in development. Several methods have been described in the literature with the objective of appropriately measuring the ovarian hormonal production, such as, surgical catheterization of the uterus-ovarian vein (Ireland et al., 1984), medium coccygeal vein (Walters et al., 1984) and caudal vena, through the lateral saphenous vein (Benot and Dailey, 1991; Rhodes et al., 1995).

These results show that the synthesis of a certain hormone not always was the reflex of its circulating level after the metabolization, according to the considerations of Harmon (1992). The progesterone is produced by the granular and theca cells (larger and smaller cells, respectively) (Murphy, 2000).

Paar (1992) found that the increase in the intake of food in the beginning of the gestation in sheeps caused an elevation in the sanguine flow in the gastrointestinal care and liver. According to Ashworth (1995), 95\% of the circulating progesterone was metabolized during a single passage through the intestine and liver. This way, a reduction would exist in the outlying concentration of progesterone.

On the other hand, Schrick et al. (1992) affirmed that the metabolites availability was one of the main factors that determined the progesterone synthesis in cows, which was associated with the circulating level of insulin. This way, the increase in the level of DMI could have elevated the production of fatty acids produced in the rumen, and consequently an increase in the level of acetate available for the cholesterol synthesis and later progesterone. 
Besides, the animals fed with $2.6 \%$ of DMI also presented a higher insulin concentration in the circulation, which was considered one of the main hormones regulators of the ovarian steroidogenesis (Spicer and Echternkamp, 1995). The insulin could have facilitated a larger availability of nutrients for the luteal tissue of these animals, resulting in the largest progesterone concentration collected from the blood in the caudal vena.

However, one should not discard the observations made with ovines, where the animals fed with a high-energy diet presented a larger progesterone catabolism. Hence, in spite of the increase in the progesterone production by the corpus luteum of the animals consuming larger amount of food, there was no difference in the circulating levels of progesterone collected from the jugular vein, a result of the catabolism of this hormone by the liver (Ashworth, 1995).

The IGF-I is a potent regulator of the bovine folicullargenesys (O'Callaghan et al., 2000) related to the increase in the answer of the follicles to the gonadotrophins (Webb et al., 1999). Spicer et al. (1992) also didn't find difference in the concentration of IGF-I of the follicular fluid in heifers after 24 to 48 hours of fast, in spite of having found difference in the sanguine concentrations of this hormone. Thus, it seemed that the concentrations of intrafollicular IGF-I were more resistant to the effects of the dietary manipulations than the systemic concentrations (O'Callaghan et al., 2000).

However, O'Callaghan et al. (2000) observed in sheeps fed with $50 \%$ or $200 \%$ of the demands of maintenance attended, smaller concentrations of IGF-I in the follicular fluids when compared to the animals fed with $100 \%$ of the maintenance demands attended.

\section{RESUMO}

O objetivo deste trabalho foi estudar o efeito do nível de ingestão de matéria seca (IMS/\% do PV) sobre as concentrações sanguíneas de glicose, insulina, urea, estrógeno e progesterona e o nível de IGF-I no líquido folicular de novilhas. Vinte e sete novilhas cruzadas foram utilizadas, distribuídas em três tratamentos: $1,2 \% ; 1,6 \%$ e $2,6 \%$ do peso vivo de ingestão de matéria seca por dia. As concentrações no plasma da veia jugular de glicose e estrógeno foram maiores nos animais com $1,6 \%$ de IMS e os níveis de insulina foram maiores nos animais com 2,6\% de IMS. Houve um aumento dos níveis plasmáticos de uréia com aumento dos níveis de IMS. Não houve efeito da IMS sobre os níveis de progesterona no plasma sangüíneo coletado da jugular. No plasma sangüíneo coletado da veia cada caudal, os níveis de progesterona foram maiores $(\mathrm{P}<0,05)$ nos animais com 2,6\% de IMS. Não houve efeito da IMS sobre os níveis foliculares de IGF-I.

\section{REFERENCES}

Armstrong, D.C.; McEvoy, T.G.; Baxter, G., (2000), Effect of dietary energy and protein on bovine follicular dynamics and embryo production in vitro: association with the ovarian insulin-like growth factor system. Biol. Repr. 1624-1632.

Ashworth, C.J., (1995), Maternal and conceptus factors affecting historophic nutrition and survival of embryos. Liv. Prod. Sci., 44, 99-105.

Basset, J.M.; Weston, R.H.; Hogan, J.P. (1971), Dietary regulation of plasma insulin and growth hormone concentration in sheep. Austr. J. Biol. Sci., 24, 321324.

Benot, A.M.; Dailey, R.A. (1991), Catheterization of the caudal vena cava via the lateral saphenus vein in the ewe, cow, and gilt: an alternative to utero-ovarian and medial coccygeal vein catheter. J. Anim. Sci., 69, 2971-2979.

Brustolini, P.C.; Silva, F.C.O.; Donzele, J.L. et al. (2004), Efeitos de fontes lipídicas e níveis de energia digestível sobre o desempenho produtivo e reprodutivo de marrãs. Arq. Bras. Méd. Vet. Zootec., 56, 511-521.

Butler, W.R. (2000), Nutritional interactions with reproductive performance in dairy cattle. Anim. Reprod. Sci., 60, 449-457.

Chagas, L.M.; Bass, J.J., Blache, D. et al. (2007), News perspectives on the roles of nutrition and metabolic priorities in the subfertility of high producting dairy cows. J. Dairy Sci., 90, 4022-4032.

Downing, J.A.; Joss, J.; Sacaramuzzi, R.J. (1995), Ovulation rate and the concentrations of gonadotrophins and metabolic hormones in ewes infused with glucose during the late luteal phase of the oestrus cycle. J. Endocr., 146, 403-410.

Elrod, C.C.; Butler, W,R. (1993), Alteration of pH in response to increased dietary protein in cattle are unique to the uterus. J. Anim. Sci., 71, 702-706.

Fergunson, J.D.; Galligan, D.T.; Blanchard, T. et al. (1993), Serum urea nitrogen and conception rate: The usefulness of test information. J. Dairy Sci., 76, 3742-3746.

Garcia-Bojalil, C.M.; Sataples, C.R.; Thatcker, W.W. et al., (1994), Protein Intake and Development of ovarian follicles and embryos of superovulated nonlactating dairy cows. J. Dairy Sci., 77, 2537-2548. 
Ginther, O.J., Wiltbank, M.C; Fricke, P.M. et al (1996), Selection of the dominant follicle in cattle. Biol. Reprod., 55, 1187-1194.

Gong, J.G.; Baxter, G.; Bramley, T.A. et al. (1997), Enhancement of ovarian follicle development in heifers by treatment with recombinant bovine somatotrophin: a dose-response study. J. Reprod. Fert., 110, 91-97.

Gutiérrez, C.G.; Oldham, J.; Bramley, T.A. et al. (1997), The recruitment of ovarian follicles is enhanced by increased dietary intake in heifers. $J$. Anim. Sci., 1876-1884.

Harmon, D.L. (1992), Impact of nutrition on pancreatic exocrine and endocrine secretion in ruminants: a review. J. Anim. Sci., 70, 1290-1301.

Ireland, J.J.; Fogwell, R.L.; Oxender, W.D. et. al. (1984), Production of estradiol by each ovary during the oestrus cycle of cows. J. Anim. Sci., 59, 764-771.

Landau, S., Houghton, J.A.S., Mawhinney, J.R. et al. (1996), Protein sources affect follicular dynamics in ewes near onset of the breeding season. Repr. Fert. Dev. 8, 1021-1028.

Landau, S.; Braw-Tal, R.; Kaim, M. et al. (2000). Preovulatory follicular status and diet affect the insulin and glucose content of follicles in highyielding dairy cows. Anim. Reprod. Sci. 62, 181-187.

Leury, B.J.; Murray, P.J.; Rowe, J.B. (1990), Effect of nutrition on the response in ovulation rate in merino ewes following short-term supplementation and insulin administration. Aust. J. Agric. Res., 41, 751759.

Molle, G. Branca, A. Ligios, S., et al., (1995), Effect of grazing backround and flushing supplementation on reproductive performance in Sarda ewes. Small rumin. Res., 17, 245-254.

Murphy, B.D. (2000), Models of luteinization. Biol. Reprod., 63, 2-11.

NATIONAL RESEARCH COUNCIL - NRC. (1996). Nutrients requeriments of beef cattle. Washinghton: National Academy of Science

O'Callaghan, D.; Boland, M.P. (1999), Nutritional effects on ovulation, embryo development and the establishment of pregnancy in ruminants. Anim. Sci., 68, 299-314.

O'Callaghan, D.; Yaakub, H.; Hyttel, P. (2000), Effect of nutrition and superovulation on oocyte morphology, follicular fluid composition hormone concentration in ewes. J. Reprod. Fert. 118, 303-313.

Paar, R.A. (1992), Nutrition-progesterone interaction during early pregnancy in sheep. Reprod. Fert. Dev., 80, 317-320.

Robinson, J.J.; Sincalir, K.D.; McEvoy, T.G. (1999), Nutritional effects on fœetal growth. J. Anim. Sci. 68, 315-332.

Rodhes, F.M.; Fitzpatrick, L.A.; Entwistle, K.W. et al. (1995), Hormone concentrations in the caudal vena cava during the first ovarian follicular wave of the oestrus cycle in heifers. J. Reprod Fert., 104, 33-39.
Santos, J.E.; Amstalden, M. (1998), Effects of nutrition on bovine reproduction. In: Arquivos da faculdade de veterinária - UFRGS. Atibaia., pp.19-89.

SAS, (1998). Statistics. SAS User's guide. SAS Institute Inc., Cary, NC.

Schrick, F.N.; Spitzer, J.C.; Gimenez, D.M. et al. (1992). Is nutritional anoestrus precipitated by subfunestronal corpora lutea in beef cows?. Domest. Anim. End., 9, 187-197.

Shaw, D.W.; Farim, P.W.; Washburn, et al. (1995), Effect of Retinol Palmitate rate and Embryo quality in superovulated cattle. Theriog., 44, 51-58.

Short, R.E.; Adams, D.C. (1988), Nutritional and hormonal interrelationships in beef cattle reproduction. Can. J. Anim. Sci., 68, 29-39.

Silva, J.F.C; Leão, M.I. (1979). Fundamentos de nutrição dos ruminantes. Editora Livroceres, Piracicaba, Brasil.

Spicer, L.J.; Crowe, M.A.; Prendiville, D.J. et al. (1992), Systemic but not intraovarian concentrations insuline-like growth factor-I are affected by shortterm fasting. Bio. Reprod., 46, 920-925.

Spicer, L.J.; Echternkamp, S.E. (1995), The ovarian insulin and insulin-like growth factor system with an emphasis on domestic animals. Dom. Anim. Endocr., 12, 223-245.

Teleni, E.; Rowe, J.B.; Crocker, H.P. (1989), Lupins and energy-yielding nutrients in ewe. II. Response in ovulation rate in ewes to increased availability of glucose, acetate and aminoacids. Reprod. Fert. Devel., 1, 117-125.

Thomas, M.G.; Bao, B., Williams, G.L. (1997),Dietary fats varyng in threir fatty acid composition differentially influence growth in cows fed isoenergetic diets. J. Anim. Sci., 75, 2512-2519.

Walters, D.L.; Schams, D.; Schallenberger, E. (1984). Pulsatile secretion of gonadotrophins, ovarian steroids and ovarian oxytocin during the luteal phase of the oestrus cycle in the cow. J. Repr. Fert., 89, 479-491.

Weeb, R.; Gosden, R.G.; Telfer, E.E. et al. (1999). Factors affecting folliculogenesis in ruminants. Anim. Sci., 68, 257-284. 